\title{
The Heating Process in an Induction Crucible Furnace and the Technology of Chromium Bronze Smelting in Order to Obtain Resistance Welding Electrodes
}

\author{
Sergei L. Busygin, Aleksandr M. Tokmin, \\ Irina S. Dementeva and Vladimir S. Kazakov* \\ Siberian Federal University \\ 79 Svobodny, Krasnoyarsk, 660041, Russia
}

Received 21.11.2017, received in revised form 20.12.2017, accepted 14.01.2018

The article describes the process of induction heating and the advantages of an induction furnace. The models of heating of the graphite crucibles and metal at different frequencies are shown. The technology of chromium bronze smelting in order to obtain cast electrodes for resistance welding is introduced in the current paper.

Keywords: induction furnace, modelling, casting, press forming, nanostructured particles, resistance welding, deterioration.

Citation: Busygin S.L., Tokmin A.M., Dementeva I.S., Kazakov V.S. The heating process in an induction crucible furnace and the technology of chromium bronze smelting in order to obtain resistance welding electrodes, J. Sib. Fed. Univ. Eng. technol., 2018, 11(2), 148-154. DOI: 10.17516/1999-494X-0018.

\section{Процессы нагрева в индукционных тигельных печах}

\section{и технология выплавки хромовой бронзы \\ Для получения электродов контактной сварки}

\author{
С.Л. Бусыгин, А.М. Токмин, \\ И.С. Дементьева, В.С. Казаков \\ Сибирский федеральный университет \\ Россия, 660041, Красноярск, пр. Свободныий, 79
}

В статье описан индукиионный способ нагрева и преимущества использования индукиионных печей. Построены модели нагрева графитового тигля и металла при разных частотах. Описана технология выплавки хромовой бронзы и получения литых электродов контактной сварки.

(c) Siberian Federal University. All rights reserved

* Corresponding author E-mail address: politex_1999@bk.ru, tam550@yandex.ru 
Ключевые слова: индукционная печь, моделирование, литье, цтамповка, наноструктурированные частицы, контактная сварка, старение.

Nowadays induction crucible melting process is widely used for melting non-ferrous metals and alloys. This technology makes it possible to produce a kind of metal, which meets the demanding requirements for castings for various purposes. The process of smelting as well as the mixing of the molten metal take place inside the induction furnace, which makes it possible to maintain the temperature of the process within certain limits. Stirring and absence of the temperature differences are, as a rule, the key factors necessary for obtaining a homogeneous copper alloy with precise chemical composition. It can also ensure the repeatability of the results in the subsequent smelting processes.

The induction method of heating is the process of heating an electrically conducting object placed in an alternating magnetic field by electromagnetic induction, through heat generated in the object. The electrical energy of the alternating type transforms into electromagnetic energy, then again into electrical one, which finally converts into thermal energy [1].

An induction crucible furnace has several advantages:

1. High heating rate and, as a result, a short duration of melting.

2. Constancy of the chemical composition and weak segregation.

3. Small combustion loss of alloying elements.

4. The possibility of isolation of the furnace workspace from the external atmosphere during the melting process.

The construction of the induction crucible furnace is presented in Fig. 1.

The program ANSYS 11.0, a finite element analysis (FEA) tool, was used for modelling the process of induction heating of a graphite crucible and metal at different frequencies. This program has been popular with various specialists for the last thirty years. The following tasks can be performed with the help of ANSYS 11.0: automatic engineering calculations (CAE, Computer-Aided Engineering), linear and nonlinear finite element analysis, stationary and non-stationary spatial tasks of the mechanics

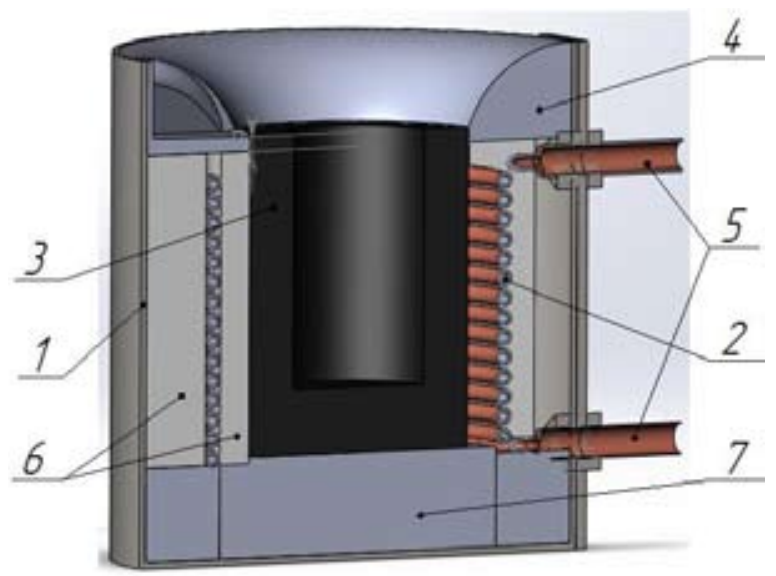

Fig. 1. The casting unit of the induction crucible furnace: 1 - cylindrical body; 2 - hollow copper tube inductor; 3 - refractory crucible; 4 - lining; 5 - current-conducting and water supply pipes; 6 - kaolin wool; 7 - refractory base 


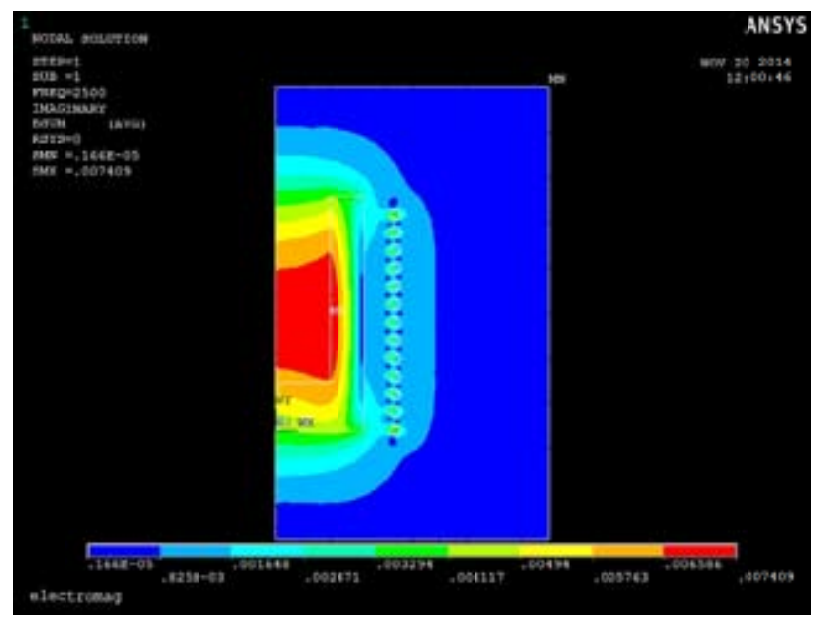

Fig. 2. The model of induction heating of a graphite crucible and metal at a frequency of $2,5 \mathrm{kHz}$

of deformable solids and structural mechanics (including nonstationary geometrically and physically nonlinear problems of contact interaction of structural elements). Other spheres include fluid mechanics, electrodynamics, acoustics and mechanics of coupled fields.

Two types of frequencies were chosen for the analysis of the connection between the current frequency influence and the heating process. At first, a model of induction heating of a graphite crucible and metal at a relatively low frequency of $2,5 \mathrm{kHz}$ was made (Fig. 2). In this case, the mixing of the metal is intensive, because the magnetic flux is relatively large and the demagnetizing effect of the induced currents is insignificant, which agrees well with the visual observation of the melting process. The distribution of the flux and the inductive currents density can be considered uniform throughout the entire cross section of the crucible at this moment. The current density is proportional to the frequency, and the energy transferred to the crucible is proportional to the square of the frequency.

The next model was made at a frequency of $44 \mathrm{kHz}$, which is widely used for induction heating. It is known [2] that as the frequency of the current increases, the energy indicators of heat increase as well, whereas the skin depth decreases.

At such a frequency, an intense heating of the graphite crucible occurs (Fig. 3). As the frequency increases, the electric field intensity in the crucible increases as well. However, this change is no longer directly proportional to the increase in frequency, since the magnetic field penetration through the crucible is weakened by demagnetization. As a result, when the frequency is increased, the energy transferred to the crucible increases proportionally to the square root of the frequency rather than to the square of the frequency [3]. Frequency modulation of the current was used in order to increase the mixing intensity at this frequency and ensure an even distribution of chromium particles over the volume of the melt.

It must be noted that the graphite crucible resistance increases at a frequency of $44 \mathrm{kHz}$. In this case, the process of its destruction is slower, because the amplitude of melt oscillation at the boundary with the crucible is much smaller than at a lower frequency of $2,5 \mathrm{kHz}$.

These models of induction heating of a graphite crucible at different frequencies show that when the frequency of the current increases, the heating of the crucible becomes more intense. 


\section{The technology of melting}

The copper melt was obtained from the waste copper scrap of the A 1/1 type (GOST 1639-93). The mass of the metal loaded into the induction crucible furnace was 1 kilo. Melting was conducted under the $25-30 \mathrm{~mm}$ thick layer of charcoal, at a frequency of $44 \pm 4 \mathrm{kHz}$. The copper melt was deoxidized with phosphorus, which was added as an alloy MF 9 (GOST 4515-93) in the amount of $0,7 \%$ [4]. An alloying element in the form of a tablet (Fig. 4), consisting of $83 \%$ of PMS-1 copper powder (GOST 4960-75) and 17\% of nanostructured chromium particles X99 (GOST 5905-79), was then added [5].

The mixing of the liquid metal took place under the influence of an alternating magnetic field with a frequency modulation of the current. It allowed to obtain an alloy with homogeneous chemical composition.

\section{The technology of obtaining the resistance welding electrodes}

The molten metal was poured into the matrix (Fig. 5). Then the alloy was cooled down to the temperature of $850-900{ }^{\circ} \mathrm{C}$ and the press forming of the cooling channel was performed with the help of a punch (Fig. 6). After that, the bottom of the matrix was opened and the electrode was pushed down into the cooling chamber located in the base of the press for quenching in running water $[6,7]$. The obtained sample of the electrode is presented in Fig. 7.

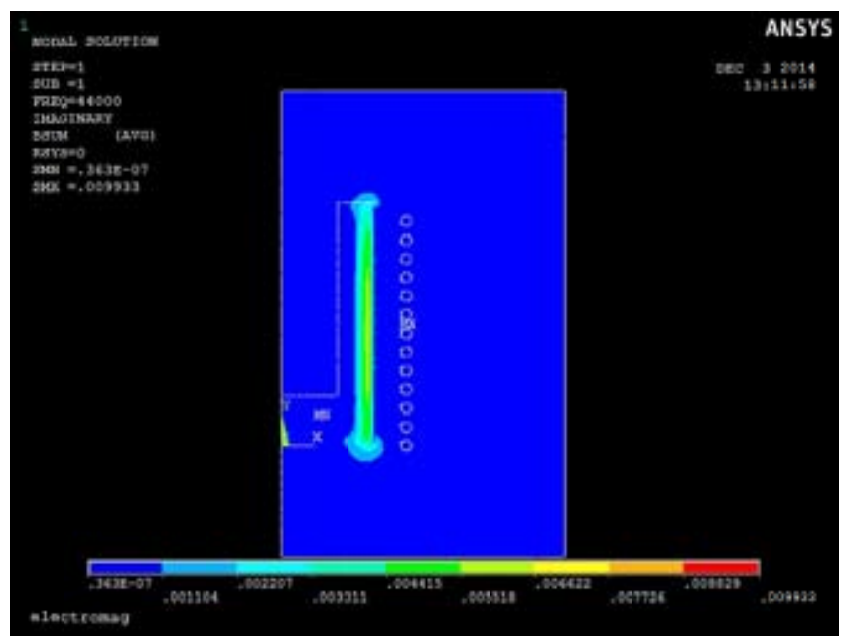

Fig. 3. The model of induction heating of a graphite crucible and metal at a frequency of $44 \mathrm{kHz}$

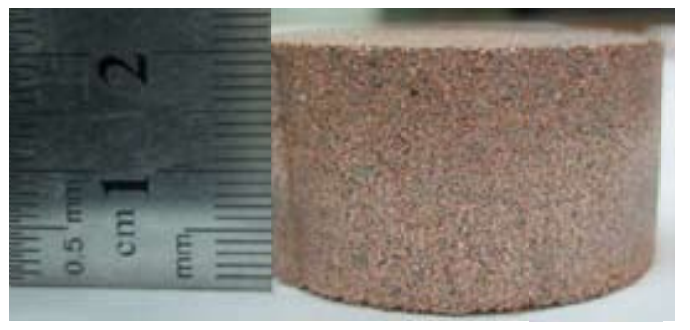

Fig. 4. An alloying element in the form of a tablet 


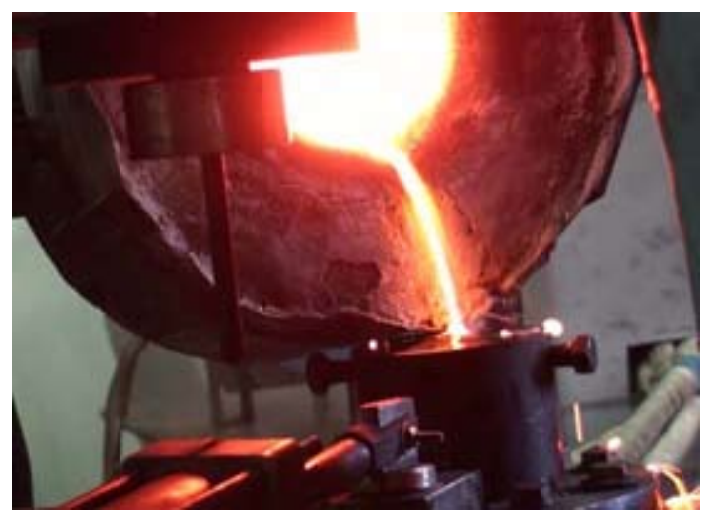

Fig. 5. Pouring the metal into the matrix

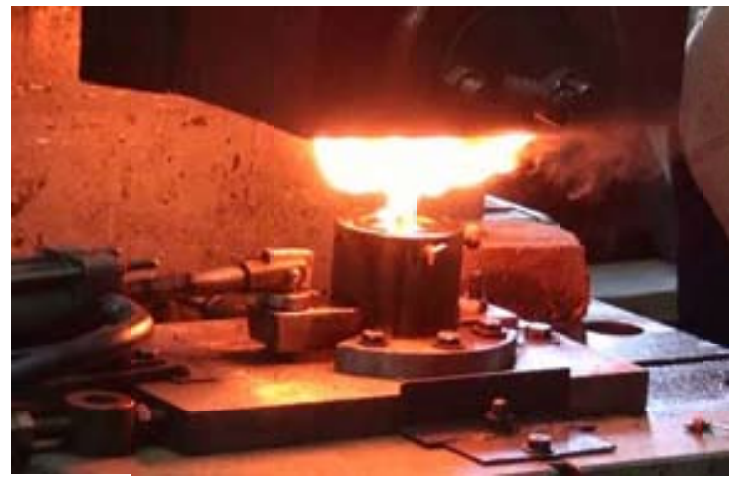

Fig. 6. Punching of the cooling channel

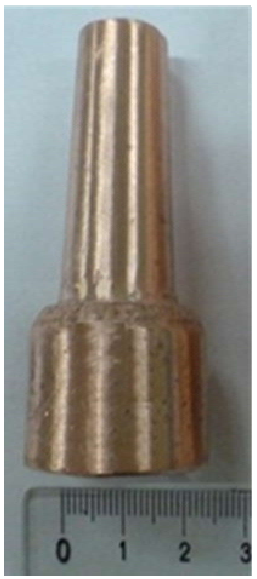

Fig. 7. The obtained sample of the electrode 
The electrode deterioration was carried out in a muffle furnace SNOL-1.62.5.1/11-IZ at the temperature of $450^{\circ} \mathrm{C}$ for $\mathbf{4}$ hours to achieve the highest level of physical and mechanical properties (strength and electrical conductivity) [8].

Based on the results of the research, the following conclusions can be drawn.

1) The models of induction heating of a graphite crucible at different frequencies show that when the current frequency increases, the heating of the crucible becomes more intense.

2) The use of copper tablets, which contain nanostructured particles of chromium, makes it possible to obtain an alloy with precise chemical composition, eliminating expensive and complicated operations of preparation of the $\mathrm{Cu}-\mathrm{Cr}$ alloy.

3) The proposed melting technology ensures a uniform distribution of chromium in the alloy due to the use of frequency modulation of the current. It has a positive effect on the strength and electrical conductivity properties of the electrodes.

4) This technology enables to produce resistance welding electrodes from secondary raw materials, which reduces the final cost of the product.

\section{Reference}

[1] Фарбман С.А., Колобнев И.Ф. Индукционные печи для плавки металлов и сплавов. М.: Металлургия, 1968. 496 c. [Farbman S.A., Kolobnev I.F. Induction furnaces for melting metals and alloys. Moscow, Metallurgiia, 1968, 496 p. (in Russian)]

[2] Слухоцкий А.Е., Рыскин С.Е. Индукторы для индукционного нагрева. Л.: Энергия, 1974, 264 c. [Slukhotskii A.E., Ryskin S.E. Inductors for induction heating. Leningrad, Energiia, 1974, 264 p. (in Russian)]

[3] Шамов А.Н., Бодажков В.А. Проектирование и эксплуатация высокочастотных установок. Л.: Машиностроение, 1974. 280 с. [Shamov A.N., Bodazhkov V.A. Design and operation of high-frequency installations. Leningrad, Mashinostroenie, 1974, 280 p. (in Russian)]

[4] Ватрушин Л.С., Осинцев В.Г., Козырев А.С. Бескислородная медь. М.: Металлургия, 1982. 192 c. [Vatrushin L.S., Osintsev V.G., Kozyrev A.S. Oxygen-free copper. Moscow, Metallurgiia, 1982, 192 p. (in Russian)]

[5] Бусыгин С.Л., Синичкин А.М., Токмин А.М. Получение электродов контактной сварки совмещенным способом литья и штамповки. Металлургия машиностроения, 2013, 2, 39-43. [Busygin S.L., Sinichkin A.M., Tokmin A.M. Obtainment of resistance welding electrodes by a combined method of casting and stamping. Metallurgiia mashinostroeniia, 2013, 2, 39-43 (in Russian)]

[6] Бусыгин С.Л., Рукосуев А.П., Крушатина С.К., Демченко А.И., Рафальский А.С. Применение ресурсосберегающей технологии металлургической переработки меди и медных сплавов для получения электродов контактной сварки. Вестник СибГАУ, 2010, 6, 119-121. [Busygin S.L., Rukosuev A.P., Krushatina S.K., Demchenko A.I., Rafalskii A.S. The use of resource-saving technology of metallurgical processing of copper and copper alloys for obtaining resistance welding electrodes. Vestnik SibGAU, 2010, 6, 119-121 (in Russian)]

[7] Бусыгин С.Л., Демченко А.И., Рафальский А.С. Способ изготовления электродов для контактной сварки. Патент РФ №2412035. Бюллетень №5, 2011 [Busygin S.L., Demchenko A.I., 
Rafalskii A.S. A method of manufacturing electrodes for resistance welding. Patent of the Russian Federation №2412035. Bulletin 5, 2011 (in Russian)]

[8] Николаев А.К., Новиков А.И., Розенберг В.М. Хромовые бронзы. М.: Металлургия, 1983. 176 c. [Nikolaev A.K., Novikov A.I., Rozenberg V.M. Chromium bronze. Moscow, Metallurgiia, 1983, 176 p. (in Russian)] 